\title{
Family healthcare expenditure on children affiliated to the Medical Insurance for a New Generation
}

\author{
Evelyne Eugenia Rodríguez-Ortega, MSc, (I) Elvira Mireya Pasillas-Torres, MSc.(I)
}

\section{Rodríguez-Ortega EE, Pasillas-Torres EM. Family healthcare expenditure on children affiliated to the Medical Insurance for a New Generation. Salud Publica Mex 20 I2;54 suppl I:S65-S72.}

\begin{abstract}
Objective. To analyze household health expenditures on children who are beneficiaries of the Medical Insurance for a New Generation (SMNG), program created in 2007 to cover healthcare costs of children without social security born after December Ist 2006. Materials and Methods. Using the SMNG National Survey, out-the-pocket and catastrophic spending on child health were calculated using several definitions. Results are presented by socioeconomic level, rural and urban areas and for Oportunidades beneficiaries. Results. About $63.3 \%$ of households spent an average annual amount of 3320 Mexican pesos (MEX\$) on healthcare for beneficiary children. Between 4.3 and II.6\% of households experienced catastrophic spending, depending on the definition adopted. Due to economic trouble, $15.5 \%$ of households postponed and $10.0 \%$ cancelled medical care for their child. Conclusions. Even though children are affiliated to the SMNG, the economic burden associated with attending their health is still an issue for families.
\end{abstract}

Keywords: healthcare financing; out-of-pocket expenditure; catastrophic expenditure; Mexico
Rodríguez-Ortega EE, Pasillas-Torres EM.

Gasto en salud de los hogares con niños afiliados al Seguro Médico para una Nueva Generación. Salud Publica Mex 20I 2;54 supl I:S65-S72.

\section{Resumen}

Objetivo. Analizar el gasto en salud y gasto catastrófico en los niños beneficiarios del Seguro Médico para una Nueva Generación (SMNG), programa creado en 2007 para niños sin seguridad social nacidos a partir del $1^{\circ}$ de diciembre de 2006. Material y métodos. Con información de la Encuesta Nacional del SMNG se calculó el gasto en salud y el gasto catastrófico de los hogares de acuerdo a varias definiciones. Los resultados se presentan por nivel socioeconómico, para zonas urbanas y rurales y por pertenencia al programa Oportunidades. Resultados. El 63.3\% de los hogares gastaron en la salud de los niños un promedio anual de 3320 pesos. Entre el 4.3 y el II.6\% de los hogares incurrieron en gasto catastrófico, dependiendo de la definición. Debido a problemas económicos, $15.5 \%$ pospuso y $10 \%$ no realizó la atención médica del niño. Conclusiones. Aún cuando los hogares están afiliados al SMNG, todavía enfrentan restricciones económicas para atender los problemas de salud del niño.

Palabras clave: financiamiento de la salud; gasto de bolsillo; gasto catastrófico; México

(I) Centro de Estudios Económicos y Sociales en Salud, Hospital Infantil de México Federico Gómez. México.

Received on: February 10, 20II - Accepted on: August II, 20II

Corresponding author: Mtra. Evelyne Eugenia Rodríguez-Ortega. Hospital Infantil de México Federico Gómez,

Dr. Gabriel Márquez 162, col. Doctores. 06720 México, DF, México

E-mail: evelyne_rodriguez@hotmail.com 
$\mathrm{T}_{8}$ he Medical Insurance for a New Generation (Seguro Médico para una Nueva Generación, SMNG), is a program for health protection for children born after December $1^{\text {st }}, 2006$, and who are not affiliated to any social security institution. SMNG's rules ${ }^{1}$ establish that affiliated children have guaranteed healthcare services and medicines without any cost to their families, and the benefits are additional and complementary to those of the Universal Catalogue of Health Services (Catálogo Universal de Servicios de Salud, CAUSES) ${ }^{2}$ and the Catastrophic Expenditure Protection Fund (Fondo de Protección de Gastos Catastróficos, FPGC). ${ }^{3}$ Therefore, health coverage for SMNG-affiliated children is financed by three sources: SMNG, CAUSES, and FPGC, which are all operated by the National Commission for Social Protection in Health (Comision Nacional de Protección Social en Salud, CNPSS), also known as Seguro Popular.

SMNG provides the following benefits in primary, secondary and tertiary healthcare: i) an integral preventive package; ii) laboratory studies for early diagnosis; and, iii) diagnosis and treatment (including all required medicines) of 116 health interventions related to the most frequent diseases of children under age 5 . In addition, for these children, CAUSES covers 109 health interventions and FPGC 44. Therefore, as children receive preventive and curative health care for all main and frequent diseases, the hypothesis is that beneficiary households should not spend money on child healthcare. Even though families can decide where to attend child health needs, the assumptions behind this hypothesis is that if health services of adequate quality were offered by the program and were accessible and available to all beneficiaries, then the beneficiaries would prefer to use these rather than any other private or public health service.

One of the program's main objectives is to reduce households' economic burden so as to avoid family impoverishment due to health problems, stated as follows:

Propitiate effective access to health services to Mexican children under 5 years of age born after December 1st 2006, and who are not affiliated to social security... through high-quality free health care as for prevention, diagnosis, treatment and rehabilitation. The SMNG benefits will be additional and complementary to those offered by CAUSES and the FPGC (numeral 2.12009 SMNG Rules). ${ }^{1}$

Therefore, if health services covered by the program were accessible and of adequate quality, and all services and medicines were timely and fully provided, households should not spend money for child healthcare, since they would prefer to use these publicly provided health services, rather than any other public or private health service, and/or they should not have to buy medicines which are otherwise provided for by the health services.

The main objective of this paper is to analyze households' out-of-pocket and catastrophic health expenditure on SMNG-affiliated children using spending associated with medical appointments, medicines, laboratory analyses, hospitalization, and traditional medicine. The analysis also includes whether households have to postpone or cancel medical attention for their children due to economic problems. Data is presented by national, urban and rural areas, socioeconomic level and affiliation to Oportunidades, a conditional cash transfer program for the poor.

\section{Materials and methods}

A descriptive analysis is carried out using information of the SMNG National Survey, ${ }^{4}$ which is representative nationwide, as well as for rural (under 2500 habitants) and urban areas. This survey is a baseline of 9107 households with children (representing 1520494 households using an appropriate expansion factor) already affiliated to the program, and information was gathered from March to April 2009 by the Instituto Nacional de Estadística y Geografía (INEGI) in association with the Hospital Infantil de México Federico Gómez (HIMFG). The sample was taken from the census of affiliated children until September $30^{\text {th }}, 2008$. The sampling design was probabilistic, multistage by conglomerates, being affiliated children the unit of analysis. The estimation of the sample size had an expected non-response rate of 30 percent. The questionnaire was desiged to gather information about children health status, use and access to health services, feeding practices and, for a subsample of children, anthropometric measures were obtained. The survey includes the household's total income and expenditure, and child health expenditure. Child healthcare spending was obtained through a series of questions about the expenditure on doctor's appointments, medicines, laboratory and other analyses, hospitalization, and traditional medicine. This survey also includes information about whether the family experienced financial problems to cover child healthcare needs, and if because of this, medical attention was postponed or cancelled. Information on how the family funded healthcare was also obtained. The SMNG National Survey had the consent of HIMFG's Ethics and Biosafety Committee.

For the analysis, households were classified by socioeconomic level using deciles of annual per capita household expenditure, with the cutoff points from the 
Households Income and Expenditure National Survey 2008 (ENIGH 2008) ${ }^{5}$ at 2009 prices, but the household healthcare expenditure reported is from SMNG National Survey. The ENIGH was used because SMNG National Survey cutoff points would not provide information about the socioeconomic level of families with SMNG beneficiaries. Per capita expenditure was used instead of per capita income since households tend to underreport income. In addition, results are presented by whether households are beneficiaries of Oportunidades (a conditional cash transfer for the poor that is the largest poverty alleviation program in Mexico), as this could affect the results on health expenditure on SMNG beneficiaries. Oportunidades includes mandatory preventive healthcare visits for all family members, including children under age 5, as well as nutritional supplements and a free Health Guaranteed Basic Pack ${ }^{6}$ (Paquete Básico Garantizado de Salud) that includes, in the case of children, prenatal and newborn care, vaccinations, nutritional and growth follow up, treatment of common childhood illnesses (respiratory, diarrhea, and first attention of accidents among others) and health education.

Calculations on catastrophic child health expenditure were done using three definitions of household's capacity to pay:

\section{Definition I:}

The household's capacity to pay is defined as effective income (or expenditure) remaining after basic subsistence needs have been met, using a food-based poverty line. This is the definition suggested by the World Health Organization (WHO, Xu K, et al 2005), ${ }^{7}$ and is calculated as:

$$
\begin{gathered}
c p_{h}=t e_{h}-\text { sube }_{h} \text { iffe } e_{h} \geq \text { sube }_{h} \\
c p_{h}=t e_{h}-f e_{h} \text { iffe }_{h}<\text { sube }_{h}
\end{gathered}
$$

where,

$c p_{h}$ is the capacity to pay of household $h$,

$t e_{h} \quad$ is total expenditure of household $h$,

$f_{h}$ is food expenditure of household $h$, and,

sube $_{h}$ is the subsistence expenditure, which is the 2008 food-

based poverty line established by CONEVAL (National

Council of Evaluation of Social Development Policy $)^{8}$ at 2009 prices for rural and urban areas

\section{Definition 2:}

The household's capacity to pay is defined as expenditure remaining after food spending:

$$
c p_{h}=t e_{h}-f e_{h}
$$

where,

$c p_{h}$ is the capacity to pay of household $h$,

$t e_{h}$ is total expenditure of household $h$, and

$f e_{h}$ is food expenditure of household $h$

\section{Definition 3:}

The household's capacity to pay is defined as expenditure remaining after food and housing spending (rent, gas and electricity), from the same survey:

$$
c p_{h}=t e_{h}-f e_{h}-v e_{h}
$$

where,

$c p_{h}$ is the capacity to pay of household $h$,

$t e_{h}$ is total expenditure of household $h$,

$f e_{h}$ is food expenditure of household $h$,

$v e_{h}$ is housing expenditure of household $h$.

In all three definitions, food expenditure excludes alcoholic and tobacco spending.

For all three definitions, catastrophic expenditure occurs if child healthcare spending is greater than or equal to $40 \%$ of the calculated capacity to pay, according to WHO 2005 guidelines. Therefore, the variable "household with catastrophic spending" is a dichotomous variable which takes the value of 1 if household $\mathrm{h}$ has catastrophic spending and 0 otherwise.

Catastrophic expenditure $=1$ if he $\geq 0.4 \times c p_{h}$
Catastrophic expenditure $h_{h}=0$ if he $<0.4 x c p_{h}$

A threshold of $30 \%$ was also calculated as some official reports of the Health Ministry use it.

\section{Results}

The SMNG program benefits mainly poor households in urban areas, as shown in Table I, since $83.0 \%$ of affiliated households are in the bottom four deciles, and $72 \%$ of households are in urban areas. The low affiliation rate in upper deciles could have two main explanations: government efforts are targeted to the poor, and better off families have more options to finance child healthcare, such as current income, savings, and private health insurance, among others. On the other hand, the ENIGH $2008^{5}$ shows that $82.2 \%$ of rural households (17.0\% nationwide) do not have social security, versus $43.1 \%$ of households ( $34.1 \%$ nationwide) in urban areas. 
Table I

TOTAL HOUSEHOLDS, PERCENTAGE OF HOUSEHOLDS WITH POSITIVE CHILD HEALTH EXPENDITURE AND AVERAGE ANNUAL HEALTH CARE EXPENDITURE, BY DECILES, URBAN/RURAL AREAS AND AFFILIATION TO OPORTUNIDADES

\begin{tabular}{lllllllllll}
\multicolumn{10}{c}{ Deciles } \\
\hline 1 & 2 & 3 & 4 & 5 & 6 & 7 & 8 & 9 & 10 & Total
\end{tabular}

\begin{tabular}{|c|c|c|c|c|c|c|c|c|c|c|c|}
\hline \multicolumn{12}{|l|}{$\mathrm{N}$ (cases) } \\
\hline National & 599123 & 301957 & $20204 I$ & 131353 & 88912 & 71645 & 45425 & 28363 & 15312 & 3716 & I 487847 \\
\hline Urban & 347508 & 229710 & 164752 & 109162 & 76412 & 62485 & 39883 & 23779 & 13707 & 3341 & I 070739 \\
\hline Rural & 251615 & 72247 & 37289 & $22|9|$ & 12500 & 9160 & 5542 & 4584 & 1605 & 375 & 417108 \\
\hline With Oportunidades & 211505 & 55467 & 23806 & 13723 & 6986 & 3343 & 1729 & 829 & 864 & 251 & 318503 \\
\hline Without Oportunidades & 387618 & 246490 & 178235 & 117630 & 81926 & 68302 & 43696 & 27534 & 14448 & 3465 & I 169344 \\
\hline \multicolumn{12}{|c|}{$\%$ of households with $>0$ spending } \\
\hline National & $51.0 \%$ & $65.8 \%$ & $68.2 \%$ & $71.4 \%$ & $77.7 \%$ & $80.6 \%$ & $86.0 \%$ & $90.0 \%$ & $85.9 \%$ & $64.9 \%$ & $63.3 \%$ \\
\hline Urban & $56.6 \%$ & $66.6 \%$ & $68.6 \%$ & $72.6 \%$ & $77.7 \%$ & $80.1 \%$ & $85.9 \%$ & $92.5 \%$ & $87.9 \%$ & $60.9 \%$ & $67.4 \%$ \\
\hline Rural & $43.1 \%$ & $63.2 \%$ & $66.3 \%$ & $65.5 \%$ & $77.4 \%$ & $84.1 \%$ & $86.5 \%$ & $77.2 \%$ & $68.6 \%$ & $100.0 \%$ & $52.9 \%$ \\
\hline With Oportunidades & $45.0 \%$ & $59.6 \%$ & $64.0 \%$ & $62.9 \%$ & $75.2 \%$ & $86.3 \%$ & $67.3 \%$ & $81.4 \%$ & $86.5 \%$ & $100.0 \%$ & $51.2 \%$ \\
\hline Without Oportunidades & $54.2 \%$ & $67.2 \%$ & $68.7 \%$ & $72.4 \%$ & $77.9 \%$ & $80.3 \%$ & $86.7 \%$ & $90.3 \%$ & $85.8 \%$ & $62.3 \%$ & $66.7 \%$ \\
\hline \multicolumn{12}{|l|}{ Average annual spending } \\
\hline National & 1646 & 2479 & 2832 & 3683 & 5402 & 5351 & 7038 & 9795 & 10426 & 22469 & 3320 \\
\hline Urban & 1654 & 2426 & 2625 & 3614 & 4938 & 5421 & 6622 & 10338 & 10034 & 9592 & 3379 \\
\hline Rural & 1632 & 2655 & 3778 & 4062 & 8249 & 4893 & 10011 & 6420 & 14719 & 92385 & 3127 \\
\hline With Oportunidades & I 476 & 2329 & 3710 & 2866 & 7843 & 9006 & 4352 & 5524 & 14978 & 137163 & 2577 \\
\hline Without Oportunidades & 1724 & 2509 & 2723 & 3766 & 5201 & 5159 & 7121 & 9911 & 10152 & $9|4|$ & 3475 \\
\hline \multicolumn{12}{|c|}{$Z$ statistics for hypothesis testing on spending } \\
\hline Urban vs rural & $3.1 *$ & $-13.5 *$ & $-33.3 *$ & $-10.6 *$ & $-25.9 *$ & $7.1^{*}$ & $-18.1 *$ & $20.1 *$ & $-6.0^{*}$ & $-13.8^{*}$ & $13.5^{*}$ \\
\hline Oportunidades vs No O & $-33.9 *$ & $-10.1^{*}$ & $21.1^{*}$ & $-20.9 *$ & $15.0^{*}$ & $12.1^{*}$ & $-25.5^{*}$ & $-16.9 *$ & $9.4 *$ & $17.1^{*}$ & $-40.6 *$ \\
\hline
\end{tabular}

Source: Own calculations based on the SMNG National Survey, Mexico

Note: Average annual spending is at 2009 Mexican pesos and only for households with child health spending >0. The total cases differ from the I 520494 households in the survey because data with missing values was not included

* Significant at 99 percent

These results suggest that a bigger effort of coverage and affiliation in health services is required in rural communities.

Although one of the program's main objectives is to reduce households' economic burden so as to avoid family impoverishment due to health problems, beneficiary households do spend on child healthcare. About $63.3 \%$ of households spent on healthcare for their SMNG- beneficiary children, with a higher percentage in urban households (Table I). However, the lower the socioeconomic level and the corresponding capacity to pay, the higher the proportion of households that do not spend money on healthcare. Why $36.7 \%$ of households do not spend in child healthcare at all represents a future line of research since the SMNG National Survey ${ }^{4}$ does not provide information about if this is due to full access to 
healthcare without cost or if household is poor enough that paying anything for child healthcare is impossible, even if that healthcare is important to maintaining their children's health.

For households who did spend on child healthcare, average annual expenditure is higher for those in urban areas than those in rural areas in 8.1\% (3 379 versus 3127 MEX\$), but child health spending represents a higher proportion of households' total expenditure in rural areas: $7.7 \%$ versus $6.1 \%$ in urban areas. At the bottom of the income distribution, using the cutoff points from the ENIGH for building the national deciles, urban and rural households spent almost the same, 1654 and 1632 MEX\$, respectively, while in the 2 to 6 deciles rural households did spend more, 2550 versus 2364 MEX \$ in urban areas, statistically different at 99 percent. One possible explanation is that access to public health services in rural areas is limited, so households have to spend more to seek health attention for children.

On the other hand, $51.2 \%$ of households' recipients of Oportunidades spent on child healthcare versus 66.7\% of non-Oportunidades beneficiaries. In addition, the out-the-pocket expenditure is $25.8 \%$ lower for Oportunidades' recipients with $2577 \mathrm{MEX}$ \$ versus $3475 \mathrm{MEX} \$$ of non-beneficiaries. This result suggests that SMNG households spent less on child healthcare not only because of the benefits of the program, but also because households are using Oportunidades health benefits. It could be a cross effect of Oportunidades. On one hand, this program provides free access to primary healthcare, being this access to health services validated prior to affiliation; on the other hand, Oportunidades' health preventive actions are compulsory for beneficiaries so it could be a reduction in disease-related morbidity. To analyze the cross effects between programs, subsequent surveys could include a set of questions relating to expenditure, morbidity, usage of SMNG healthcare services and of other social programs that award medical and preventive attention, including Oportunidades. The SMNG National Survey ${ }^{4}$ only provides information about whether families are beneficiaries of Oportunidades and not if those affiliated households are using health care from one or both programs.

Regarding catastrophic expenditure, the percentage of households that spent more than $40 \%$ of their capacity to pay on child healthcare ranges from $4.3 \%$ to $6.8 \%$, depending on the definition of households' capacity to pay (Table II). Using the $30 \%$ threshold of the households' capacity to pay, the percentage of households with catastrophic spending goes from $7.4 \%$ to 11.6 percent.

The proportion of households with catastrophic spending is lower for Oportunidades' recipients with all three definitions. Using the 40\% threshold and definition 1 of households' capacity to pay (WHO definition), ${ }^{7} 3.5 \%$ of Oportunidades beneficiaries experienced catastrophic expenditure versus $4.5 \%$ of non-Oportunidades recipients, a significant statistical difference at 99 percent.

In relation to the composition of healthcare expenditure, medicines represent $57.2 \%$ and medical appointments $34.3 \%$ of total child healthcare expenditure, as shown in Table III. The composition of healthcare spending is very similar between Oportunidades beneficiaries and non-beneficiaries. Medicines represent the largest spending item for affiliated households, although the proportion is lower for households with catastrophic expenditure: $49.4 \%$ versus $60.1 \%$. The difference implies higher spending in medical appointments, hospitalization and laboratory studies for households with catastrophic expenditure. Hospitalization for these households represents $6.0 \%$ of total health care spending. It must be noted that only $5.6 \%$ of households had hospitalized children.

When a child requires medical care, parents and family members are not only concerned about the illness, but also how they will afford healthcare, especially in low income households. Table IV presents households' financing sources, in addition to current income, to pay for child healthcare, such as savings, loans from family and friends or banks, and selling or pawning of assets. Thirty-six point six percent $(36.6 \%)$ of all households used some sort of financing to pay for child medical care, even though the children are affiliated to the program. This percentage is lower for Oportunidades beneficiaries with $32.8 \%$ versus $37.7 \%$ for non-beneficiaries. The most important source of financing is loans from family and friends, since $25.7 \%$ of households used them, affecting future consumption, as the loan has to be repaid.

Households with catastrophic expenditure had higher need of external resources to fund medical care for their children with $72.6 \%$ versus against $35.0 \%$ of households without catastrophic spending also relying on loans from family and friends as the most important source of financing with $52.1 \%$, while $17.1 \%$ used savings and 10.7 pawned family assets. These figures show that even though children are beneficiaries of SMNG, their families had to depend on external resources to finance medical care at the expense of future consumption.

Health care costs and financial constraints of households also made them postpone and/or cancel child healthcare. Even though all children in the survey are affiliated to SMNG, as shown in Table V, 15.5\% of households postponed medical attention for their children at least once because of financial problems, and $10.1 \%$ cancelled healthcare altogether. These per- 
Table II

Percentage of households With Catastrophic expenditure in Child healthcare (USING TWO THRESHOLDS AND THREE DEFINITIONS OF HOUSEHOLD'S CAPACITY TO PAY)

\begin{tabular}{lllllllllll}
\multicolumn{10}{c}{ Deciles } \\
\hline 1 & 2 & 3 & 4 & 5 & 6 & 7 & 8 & 9 & 10 & Total
\end{tabular}

National

$40 \%$ threshold

\begin{tabular}{|c|c|c|c|c|c|c|c|c|c|c|c|}
\hline Definition I & 4.8 & 3.7 & 3.0 & 4.0 & 6.9 & 3.6 & 5.0 & 4.4 & 4.2 & 3.8 & 4.3 \\
\hline Definition 2 & 4.8 & 3.7 & 3.2 & 4.4 & 7.0 & 3.8 & 6.0 & 5.6 & 5.3 & 3.8 & 4.5 \\
\hline Definition 3 & 7.8 & 6.0 & 4.5 & 6.0 & 8.3 & 5.4 & 10.8 & 7.1 & 9.2 & 3.8 & 6.8 \\
\hline \multicolumn{12}{|c|}{$30 \%$ threshold } \\
\hline Definition I & 8.3 & 6.6 & 5.8 & 7.0 & 9.7 & 5.2 & 9.7 & 6.3 & 6.0 & 3.8 & 7.4 \\
\hline Definition 2 & 8.3 & 6.6 & 6.0 & 7.7 & 10.1 & 5.8 & 12.2 & 9.7 & 9.7 & 3.8 & 7.7 \\
\hline Definition 3 & 12.5 & 10.5 & 9.7 & II.I & 11.5 & 9.4 & 16.7 & 16.6 & 16.2 & 3.8 & 11.6 \\
\hline
\end{tabular}

With Oportunidades

$40 \%$ threshold

\begin{tabular}{llllllllllll} 
Definition I & 3.1 & 2.3 & 7.4 & 3.7 & 8.2 & 10.4 & - & - & - & 57.0 & 3.5 \\
\hline Definition 2 & 3.1 & 2.3 & 7.4 & 5.5 & 9.4 & 10.4 & - & - & - & 57.0 & 3.6 \\
Definition 3 & 5.3 & 3.3 & 8.1 & 5.5 & 15.2 & 10.4 & - & - & - & 57.0 & 5.4
\end{tabular}

Without Oportunidades

$40 \%$ threshold

\begin{tabular}{|c|c|c|c|c|c|c|c|c|c|c|c|}
\hline Definition I & 5.7 & 4.0 & 2.4 & 4.0 & 6.8 & 3.2 & 5.2 & 4.6 & 4.5 & - & 4.5 \\
\hline Definition 2 & 5.7 & 4.0 & 2.7 & 4.3 & 6.8 & 3.5 & 6.3 & 5.7 & 5.6 & - & 4.7 \\
\hline Definition 3 & 9.2 & 6.7 & 4.1 & 6.0 & 7.7 & 5.2 & 11.2 & 7.4 & 9.8 & - & 7.2 \\
\hline
\end{tabular}

Source: Own calculations based on the SMNG National Survey, Mexico

Note: Differences between Oportunidades and non-Oportunidades are significant at 99 percent

Table III

\section{COMPOSITION OF CHILD HEALTH CARE EXPENDITURE}

\begin{tabular}{|c|c|c|c|c|c|}
\hline & \multicolumn{2}{|c|}{ Catastrophic expenditure } & \multicolumn{2}{|c|}{ Oportunidades } & \multirow[b]{2}{*}{ Total } \\
\hline & Yes & No & Yes & No & \\
\hline Medical appointments & $37.1 \%$ & $33.2 \%$ & $34.4 \%$ & $33.5 \%$ & $34.3 \%$ \\
\hline Medicines & $49.8 \%$ & $60.1 \%$ & $57.3 \%$ & $56.5 \%$ & $57.2 \%$ \\
\hline Laboratory studies & $6.7 \%$ & $3.7 \%$ & $4.4 \%$ & $5.1 \%$ & $4.5 \%$ \\
\hline Tradicional medicine & $0.5 \%$ & $1.4 \%$ & $1.0 \%$ & $1.8 \%$ & $1.2 \%$ \\
\hline Hospitalization & $6.0 \%$ & $1.6 \%$ & $2.8 \%$ & $3.1 \%$ & $2.8 \%$ \\
\hline Total & $100.0 \%$ & $100.0 \%$ & $100.0 \%$ & $100.0 \%$ & $100.0 \%$ \\
\hline
\end{tabular}

Source: Own calculations based on the SMNG National Survey, Mexico

Note: Households with catastrophic expenditure, using the WHO definition

centages are higher for households with catastrophic healthcare expenditure, $26.5 \%$ and $18.3 \%$, respectively. The numbers are slightly lower for Oportunidades' recipients, since $14.0 \%$ postponed and $9.4 \%$ cancelled child healthcare versus $15.9 \%$ and $10.2 \%$, respectively, for non-Oportunidades beneficiaries.

\section{Conclusions}

The SMNG National Survey ${ }^{4}$ shows that the program is primarily supporting poor households, since $83 \%$ are in the poorer four deciles of the population. Coverage is concentrated in urban areas at $72 \%$. These results 
Table IV

Percentage of households that used additional financial sources to current INCOME TO PAY CHILD HEALTHCARE

\begin{tabular}{|c|c|c|c|c|c|c|c|c|c|c|}
\hline & \multicolumn{4}{|c|}{ Catastrophic expenditure } & \multicolumn{4}{|c|}{ Oportunidades } & \multirow{2}{*}{\multicolumn{2}{|c|}{ Total }} \\
\hline & \multicolumn{2}{|c|}{ Yes } & \multicolumn{2}{|c|}{ No } & \multicolumn{2}{|c|}{ Yes } & \multicolumn{2}{|r|}{ No } & & \\
\hline & $\%$ & $N$ & $\%$ & $N$ & $\%$ & $N$ & $\%$ & $N$ & $\%$ & $N$ \\
\hline Household's savings & I7.I & 10926 & 9.0 & 127484 & 7.8 & 24971 & 9.7 & 113439 & 9.3 & 138410 \\
\hline \multicolumn{11}{|l|}{ Loans from friends and family } \\
\hline (not members of the household) & 52.1 & 33395 & 24.5 & 348419 & 23.9 & 76047 & 26.1 & 305767 & 25.7 & 381814 \\
\hline Sells of properties, furnisher and livestock & 6.3 & 4038 & 1.3 & 18113 & 1.9 & 6008 & 1.4 & 16143 & 1.5 & $22|5|$ \\
\hline Pawn of items & 10.7 & 6862 & 3.7 & 52554 & 2.3 & 7307 & 4.5 & 52109 & 4.0 & 59416 \\
\hline Bank & 2.2 & I 426 & 0.4 & 5668 & 0.1 & 263 & 0.6 & 6831 & 0.5 & 7094 \\
\hline One or more sources & 72.6 & 46514 & 35.0 & 498642 & 32.8 & 104397 & 37.7 & 440759 & 36.6 & 545156 \\
\hline None & 27.4 & 17559 & 65.0 & 925132 & 67.2 & 214106 & 62.3 & 728585 & 63.4 & 942691 \\
\hline Total (households) & 100.0 & 64073.0 & 100.0 & I 423774 & 100.0 & 318503 & 100.0 & I 169344 & 100.0 & I 487847 \\
\hline
\end{tabular}

Source: Own calculations based on the SMNG National Survey, Mexico

Note: Percentages by column do not add up to 100 percent because a household can use one or more of the financing sources. Households with catastrophic expenditure based on WHO's definition

Table V

Percentage of households that postponed or cancelled child medical care DUE TO FINANCIAL PROBLEMS

\begin{tabular}{|c|c|c|c|c|c|c|c|c|c|c|}
\hline & \multicolumn{4}{|c|}{ Catastrophic expenditure } & \multicolumn{4}{|c|}{ Oportunidades } & \multirow{2}{*}{\multicolumn{2}{|c|}{ Total }} \\
\hline & & & & & & & & Vo & & \\
\hline & $\%$ & N & $\%$ & $\mathrm{~N}$ & $\%$ & $N$ & $\%$ & $\mathrm{~N}$ & $\%$ & $N$ \\
\hline Postponed & 100.0 & 64,073 & 100.0 & I,423,774 & 100.0 & 318,503 & 100.0 & I,I69,344 & 100.0 & I,487,847 \\
\hline Yes & 26.5 & 16,972 & 15.0 & 213,374 & 14.0 & 44,638 & 15.9 & 185,389 & 15.5 & 230,323 \\
\hline No & 73.0 & 46,798 & 84.0 & $\mathrm{I}, 196,552$ & 85.4 & 271,983 & 83.2 & 973,136 & 83.6 & $\mathrm{I}, 243,37 \mathrm{I}$ \\
\hline Did not know/did not answer & 0.5 & 303 & 1.0 & 13,848 & 0.6 & I,882 & 0.9 & 10,819 & 1.0 & 14,153 \\
\hline Cancelled & 100.0 & 64,073 & 100.0 & $\mathrm{I}, 423,774$ & 100.0 & 318,503 & 100.0 & $\mathrm{I}, 169,344$ & 100.0 & $\mathrm{I}, 487,847$ \\
\hline Yes & 18.3 & 11,735 & 9.7 & $|38,68|$ & 9.4 & 30,072 & 10.2 & 119,295 & 10.0 & 149,367 \\
\hline No & 81.7 & 52,338 & 90.1 & $|, 283,47|$ & 90.5 & 288,230 & 89.7 & $\mathrm{I}, 048,888$ & 89.9 & $1,337,118$ \\
\hline Did not know/did not answer & - & - & 0.1 & $\mathrm{I}, 622$ & 0.1 & 201 & 0.1 & $|| 6 \mid$, & 0.1 & 1,362 \\
\hline
\end{tabular}

Source: Own calculations based on the SMNG National Survey, Mexico

Note: This information was gathered from the following questions: Because of economic trouble, in the last 12 months, did you have to:

i) Postpone or wait to attend to the health of (name of the child)? (Possible responses: Yes, No, Don't know)

ii) Not attend to the health problem of (name of the child)? (Possible responses: Yes, No, Don't know)

Results from question i) are presented in "Postponed" and results from question ii) are presented in "Cancelled"

imply that even though the program is reaching poorer children, additional efforts are necessary to affiliate the rural population, especially the poor who have low coverage through social security. Regarding child health expenditure, urban and rural households in the decile 1 spent almost the same, 1654 and $1632 \mathrm{MEX} \$$, respectively, while in the 2 to 6 deciles, rural households spent more, 2550 versus 2364 MEX\$ in urban areas, a 99\% statistically significant difference.

Although children are affiliated to the SMNG, the economic burden for families for child healthcare is still important: $4.3 \%$ of households faced catastrophic child 
health expenditure, and this percentage could be up to $11.6 \%$, depending on the definition used. In addition, $36.7 \%$ of affiliated households used external sources of financing to pay for child healthcare, the most frequent being loans from family and friends. Regarding the decisions on health due to financial problems, 15.5\% of households postponed and $10.1 \%$ cancelled child medical attention. Oportunidades beneficiaries do better regarding economic burden: out-the-pocket spending is lower, as is the percentage of families with catastrophic spending. On the other hand, medicines and medical appointments represent the higher proportion of healthcare spending for SMNG-affiliated households with or without catastrophic spending.

Results from the SMNG National Survey show that economic burden is important for affiliated families. Therefore, improvements to the program are required to reduce out-the-pocket health spending and catastrophic expenditure. It is necessary to increase effective access through more and better health services, mainly in rural areas, and to improve the mechanisms to ensure that households are well informed about the benefits offered by the program.

It is important to mention that this study has several limitations so that its results should be interpreted with care. First, the analysis did not have a basal survey and a comparison group, so the impact of the program on children healthcare expenditure is not measured. The program did not obtain baseline data previous to the beginning of the SMNG, and the SMNG National Survey could not get a comparison group since the SMNG and Seguro Popular were already widespread. Second, since questions about household income were limited and it could be underreported, per capita spending was used to classify families by socioeconomic level, instead. Finally, the SMNG National Survey detected confusion among beneficiaries about affiliation to the SMNG; an important percentage of families did not know they were affiliated to the SMNG, instead they mentioned affiliation to Seguro Popular. Since this fact was not expected in the design of the questionnaire, families that mentioned not to be affiliated to SMNG were not asked about access and utilization of SMNG services.
Therefore, due to this lack of information, this study did not include a relation between healthcare expenditure and use of program's health services, so a possible bias may be present in spending data by households' decision making about using or not using health services.

Among the strengths of this study, it can be mentioned that the survey was fully conducted by INEGI, with highly experienced staff; the sampling design allows generalizing results at urban, rural and national levels. In addition, these results can be taken as a baseline evaluation of the program for subsequent surveys, and for defining public policies, since this study points out opportunities of improvement for the program to reduce healthcare expenditure.

\section{Acknowledgments}

To Onofre Muñoz Hernández MD, for his valuable comments. To Silvia Martínez-Valverde and Guillermo Salinas-Escudero for their assistance in handling the survey.

Declaration of conflicts of interest: The authors declare that they have no conflict of interests.

\section{References}

I. Secretaría de Salud. Reglas de operación SMNG 2009. Mexico D.F., Mexico. Diario Oficial de la Federación, December 30, 2008.

2. Comisión Nacional de Protección Social en Salud. Catálogo Universal de Servicios de Salud. México: CNPSS, 2008.

3. Catálogo de Intervenciones del FPGC. [Online] [Cited: Agust 5, 20I0.] available at http://seguro-popular.gob.mx/images/contenidos/FPGC/ Catalogofpgc.pdf.

4. Hospital Infantil de México, INEGI. Encuesta del SMNG National Survey. México: HIMFG/INEGI, 2009.

5. Instituto Nacional de Estadística y Geografía. Households Income and Expenditure National Survey (ENIGH). México: INEGI, 2008.

6. Oportunidades. Reglas de operación 2009. Mexico D.F., Mexico, Diario Oficial de la Federación, December 29, 2008.

7. Xu K, Aguilar AM, Vans DV, Hanvoravongchai P, Kawabata K, Klavus J, et al. Distribución del gasto en salud y gastos catastróficos, metodología. Geneva: World Health Organization, 2005.

8. Consejo Nacional de Evaluación de la Política de Desarrollo Social. 2008 Poverty Lines. [Online] [Accesed: 2009 June I] Available at www. coneval.gob.mx. 